\title{
Factors affecting online purchase intention: A study of Vietnam online customers
}

\author{
Thu-Trang Thi Doan ${ }^{\mathrm{a}^{*}}$ \\ ${ }^{a}$ Faculty of Finance and Banking, Industrial University of Ho Chi Minh City (IUH), Vietnam \\ A B S T R A C T
}

\begin{tabular}{l}
\hline C H R O N I C L E \\
\hline Article history: \\
Received: January 28, 2020 \\
Received in revised format: \\
January 302020 \\
Accepted: February 29, 2020 \\
Available online: \\
March 2, 2020 \\
\hline Keywords: \\
Online purchase intention \\
Performance expectancy \\
Effort expectancy \\
Social influence \\
Facilitating conditions \\
UTAUT \\
\hline
\end{tabular}

The paper examines factors influencing online purchase intention of Vietnamese. Based on the Unified Theory of Acceptance and Use of Technology (UTAUT), the study develops a theoretical model including four explanatory variables of online purchase intention: performance expectancy (PE), social influence (SI), effort expectancy (EE) and facilitating conditions (FC). The empirical results obtained in a sample of 204 valid interviewees reveal the statistically significant and concurrent impact of the mentioned determinants on the intention to purchase online. Among them, performance expectancy (PE) and social influence (SI) exert the most significant influence. The findings provide guidance for online firms to improve their conditions and develop marketing strategies in order to highlight efficiency, ease of use, and convenience; become a trend of social communities and then encourage the online purchase.

\section{Introduction}

With the development of Internet, electronic commerce has brought big revolutionary challenges in business. According to data from Internet World Stats, $52 \%$ of the world population are internet users in 2018 . This shows enormous potential of online trading. Specifically, in the recent two decades, internet trading has grown dramatically (Internet World Stats, 2018). According to eMarketer, global online sales reached 2,300 billion US dollars in 2017 and is anticipated to keep growing to be 4,880 billion US dollars in 2021 (EMarketer, 2018). Together with this global development, Vietnam online trading has also increased considerably. According to the E-business Index Report 2018, Vietnam E-commerce Association (VECOM) estimated that the growth rate of e-commerce in 2017 compared to the previous year was over $25 \%$ and forecasted this trend would continue to grow in the following years. Also, in this report, VECOM shows the outstanding growth rate in specific fields which is $35 \%$ and $62 \%$ respectively for online retailing and courier service, for example (Vietnam E-commerce Association, 2018). This development of e-commerce in recent time confirms that the trend of online shopping has become more and more popular in Vietnam. This retailing channel attracts lots of attention from retailers and businessmen thanks to its significant impact on other traditional channels. Further, its benefits such as ease for shopping and price comparison, 24/7 service act as stimulants to internet shopping. On the other hand, one of its disadvantages is the fact that consumers may experience lack of product information, problems in using online systems, dissatisfaction with purchased items or even risks in payment. Accordingly, it is necessary to understand customers' expectation and determinants affecting their shopping intention. Singh et al. (2017) emphasized that to boost the intention of shoppers is a strategy of online firms to improve profits. In fact, many scholars have conducted research on online purchase intention in the world. However, this is the first research employing the Unified Theory of Acceptance and Use of Technology (UTAUT) to study factors which exert influence on the online purchase intention in Vietnam, so it plays an essential role in attracting customers for online businesses. In addition, the paper is also a valuable reference for scholars who study the purchase intention in general and online purchase intention in specific. 


\section{Literature review}

\subsection{Purchase intention}

Intention is considered to be an indicator evaluating how people are willing to access to a certain behaviour and effort to perform it (Ajzen, 1991). Specifically, in respect of a purchase behaviour, purchase intention is defined as the willingness of an individual to buy an item (Tirtiroglu \& Elbeck, 2008; Raza et al., 2014). Indeed, how the business operates can be evaluated on the shopping intention of its customers (Howard \& Sheth, 1967).

To e-commerce businesses, it is even more important to identify their customers' intention. According to He et al. (2008), lack of online purchase intention is a serious obstacle of e-commerce development and greatly influences online business.

\subsection{Unified Theory of Acceptance and Use of Technology (UTAUT)}

UTAUT is developed on the basis of eight theories and models that explain the acceptance of technology (Venkatesh et al., 2003). Like previous theories of acceptance to use technology, the UTAUT assumes that behavioural intention is the factor which exerts the most significant influence on real use behaviour of a customer. This research emphasizes behavioural intention can be explained for $70 \%$ cases of real use behaviour, being superior to the earlier studies (with their explanation at 30 to 45 percent). By another analysis, Martín and Herrero (2012) also use the UTAUT to examine the impact of the user's psychological factors on the online purchase intention in rural tourism. The theory identifies four key determinants including performance expectancy, effort expectancy, social influence and facilitating conditions. The results report that the online purchase intention is correlated to the levels of performance expectancy and effort expectancy. On contrary, there is no statistically significant influence of social influence and facilitating conditions on the online purchase intention. Likewise, based on the UTAUT, Escobar-Rodríguez and Carvajal-Trujillo (2014) analyse the key factors affecting the intention and behaviour to use websites of low-cost airlines to book a flight. The findings also reveal four key drivers of the intention to book flights which are performance expectancy, effort expectancy, social influence and facilitating conditions. These are consistent with what have been found by Abrahão et al. (2016), Sarfaraz et al. (2017), Singh et al. (2017) and Isaac et al. (2019). It can be concluded that the UTAUT is superior to any of previous theories. Therefore, the UTAUT is adopted to determine factors which are correlated to the online purchase intention of Vietnamese customers.

The four key drivers of the intention to purchase online mentioned in this research include:

- Performance Expectancy: is defined as "the degree to which the user expects that using the system will help him or her to attain gains in job performance"

- Effort Expectancy: shows "the degree of ease associated with the use of the system" which is perceived by a user utilizing a system or a technology. This concept believes that the use of the system will be easy and effortless.

- Social Influence: is understood as "the degree to which an individual perceives that important others believe he or she should use the new system". Social influence is considered as a key determinant which directly affects the use intention shown by subjective norm which is introduced in other models like TRA.

- Facilitating Conditions: refers "the degree to which an individual believes that an organizational and technical infrastructure exists to support use of the system”.

\section{Data and Methodology}

\subsection{Data Collection}

The research is conducted in Vietnam from November $5^{\text {th }}, 2018$ to May $10^{\text {th }}, 2019$. Data are collected using a questionnaire in two ways: delivering it directly to participants and the one created on Google Docs by online tools such as email, some social network (Facebook, shopping forums). According to Roy and Ghose (2006), the acceptance of online purchase is twophase adoption - adoption the Internet use as the first stage and using it for shopping as the second stage. Consequently, the respondents are Internet users, especially those have ever accessed shopping websites. Before an official survey, a test is conducted to ensure the validity and reliability of the questionnaire. A total of 600 paper and online questionnaire forms are delivered, in which 356 forms are collected with 152 invalid ones since the respondents provide lack of online shopping experience or information. A total of 204 valid are thus used.

\subsection{Methodology}

The research employs exploratory factor analysis (EFA) to evaluate the influence levels of the determinants on the online purchase intention of users in Vietnam. SPSS statistics is also chosen in data analysis.

Based on the UTAUT, the following theoretical model is suggested:

$$
\mathrm{PI}=\beta_{0}+\beta_{1} \times \mathrm{PE}+\beta_{2} \times \mathrm{EE}+\beta_{3} \times \mathrm{FC}+\beta_{4} \times \mathrm{SI}+\varepsilon
$$

Dependent variable: Online purchase intention (PI)

Independent variables: Performance expectancy (PE), effort expectancy (EE), facilitating conditions (FC), social influence (SI). 


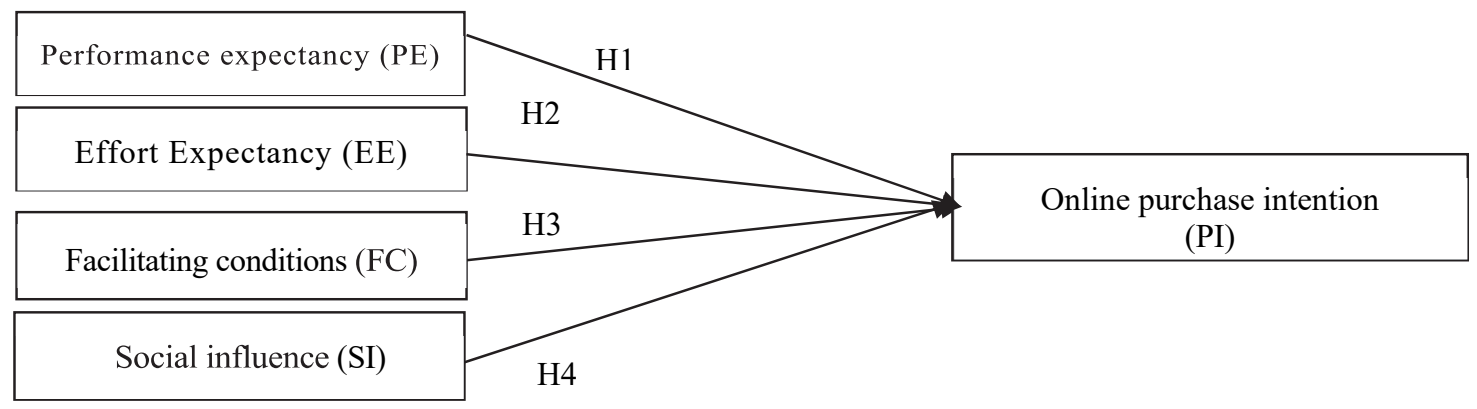

Source: suggested by the author.

Fig. 1. Proposed theoretical model

The survey is developed on the previous theoretical and empirical models, combining with the constructing a new questionnaire in order to bring the novelty and appropriateness to the reality of the topic. The survey is specifically designed as follows:

Table 1

Measuring scales and references for the proposed constructs.

\begin{tabular}{|c|c|c|c|}
\hline $\begin{array}{c}\text { Varia- } \\
\text { bles }\end{array}$ & Code & Definitions & References \\
\hline \multirow{5}{*}{ 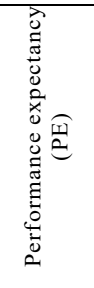 } & PE1 & $\begin{array}{l}\text { Users have lots of chances to search for } \\
\text { useful items }\end{array}$ & Newly constructed \\
\hline & PE2 & Users are able to save time & $\begin{array}{l}\text { Venkatesh et al. (2003); Martín and Herrero (2012); Escobar-Rodríguez and Carvajal-Trujillo } \\
\text { (2014); Abrahão et al. (2016); Sarfaraz (2017); Isaac et al. (2019). }\end{array}$ \\
\hline & PE3 & $\begin{array}{l}\text { Users do not need to visit traditional } \\
\text { shops frequently }\end{array}$ & Venkatesh et al. (2003); Martín and Herrero (2012); Sarfaraz (2017). \\
\hline & PE4 & $\begin{array}{l}\text { Users are able to improve shopping per- } \\
\text { formance }\end{array}$ & $\begin{array}{l}\text { Venkatesh et al. (2003); Martín and Herrero (2012); Escobar-Rodríguez and Carvajal-Trujillo } \\
\text { (2014); Abrahão et al. (2016); Sarfaraz (2017); Isaac et al. (2019). }\end{array}$ \\
\hline & PE5 & Users are able to improve living standard & $\begin{array}{l}\text { Venkatesh et al. (2003); Martín and Herrero (2012); Escobar-Rodríguez and Carvajal-Trujillo } \\
\text { (2014); Abrahão et al. (2016); Sarfaraz (2017); Isaac et al. (2019). }\end{array}$ \\
\hline \multirow{4}{*}{ 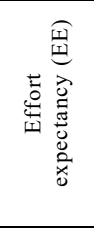 } & EE1 & $\begin{array}{l}\text { Users can easily use the shopping web- } \\
\text { sites }\end{array}$ & $\begin{array}{l}\text { Venkatesh et al. (2003); Martín and Herrero (2012); Escobar-Rodríguez and Carvajal-Trujillo } \\
\text { (2014); Abrahão et al. (2016); Sarfaraz (2017); Isaac et al. (2019). }\end{array}$ \\
\hline & EE2 & $\begin{array}{l}\text { The instruction of shopping websites is } \\
\text { clear and easy to understand }\end{array}$ & $\begin{array}{l}\text { Venkatesh et al. (2003); Martín and Herrero (2012); Escobar-Rodríguez and Carvajal-Trujillo } \\
\text { (2014); Abrahão et al. (2016); Sarfaraz (2017); Isaac et al. (2019). }\end{array}$ \\
\hline & EE3 & $\begin{array}{l}\text { Online shopping procedures are quite } \\
\text { simple for users }\end{array}$ & $\begin{array}{l}\text { Venkatesh et al. (2003); Martín and Herrero (2012); Escobar-Rodríguez and Carvajal-Trujillo } \\
\text { (2014); Abrahão et al. (2016); Sarfaraz (2017); Isaac et al. (2019). }\end{array}$ \\
\hline & EE4 & $\begin{array}{l}\text { Users can purchase easily with instruc- } \\
\text { tions }\end{array}$ & Newly constructed \\
\hline \multirow{4}{*}{ 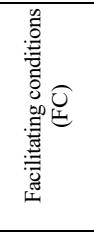 } & FC1 & $\begin{array}{l}\text { Users have adequate resources for the } \\
\text { online purchase }\end{array}$ & $\begin{array}{l}\text { Venkatesh et al. (2003); Martín and Herrero (2012); Escobar-Rodríguez and Carvajal-Trujillo } \\
\text { (2014); Isaac et al. (2019). }\end{array}$ \\
\hline & $\mathrm{FC} 2$ & $\begin{array}{l}\text { Users have enough understanding on the } \\
\text { online purchase }\end{array}$ & $\begin{array}{l}\text { Venkatesh et al. (2003); Martín and Herrero (2012); Escobar-Rodríguez and Carvajal-Trujillo } \\
\text { (2014). }\end{array}$ \\
\hline & $\mathrm{FC} 3$ & $\begin{array}{l}\text { The shopping websites are compatible } \\
\text { with users' equipment }\end{array}$ & $\begin{array}{l}\text { Venkatesh et al. (2003); Martín and Herrero (2012); Escobar-Rodríguez and Carvajal-Trujillo } \\
\text { (2014). }\end{array}$ \\
\hline & FC4 & $\begin{array}{l}\text { The shopping websites are integrated } \\
\text { with different payment methods }\end{array}$ & Newly constructed \\
\hline \multirow{3}{*}{ 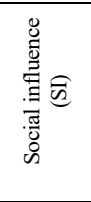 } & SI1 & $\begin{array}{l}\text { Most of their acquaintances (relatives, } \\
\text { friends...) recommend online purchase } \\
\text { to users }\end{array}$ & $\begin{array}{l}\text { Venkatesh et al. (2003); Martín and Herrero (2012); Escobar-Rodríguez and Carvajal-Trujillo } \\
\text { (2014); Abrahão et al. (2016); Sarfaraz (2017); Isaac et al. (2019). }\end{array}$ \\
\hline & SI2 & $\begin{array}{l}\text { Working/ studying environment of users } \\
\text { are supportive to the online shopping }\end{array}$ & Venkatesh et al. (2003); Martín and Herrero (2012); Abrahão et al. (2016); Sarfaraz (2017). \\
\hline & SI3 & $\begin{array}{l}\text { Users think that online purchase suits the } \\
\text { current trend }\end{array}$ & Newly constructed \\
\hline \multirow{3}{*}{ 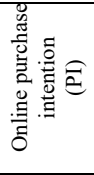 } & PI1 & $\begin{array}{l}\text { Users tend to purchase online or keep } \\
\text { purchasing online in the future }\end{array}$ & Venkatesh et al. (2003); Martín and Herrero (2012); Abrahão et al. (2016); Sarfaraz (2017). \\
\hline & PI2 & $\begin{array}{l}\text { Users are going to purchase more fre- } \\
\text { quently if possible }\end{array}$ & $\begin{array}{l}\text { Venkatesh et al. (2003); Escobar-Rodríguez and Carvajal-Trujillo (2014); Abrahão et al. } \\
\text { (2016); Isaac et al. (2019). }\end{array}$ \\
\hline & PI3 & $\begin{array}{l}\text { Users tend to recommend online pur- } \\
\text { chase to their friends and family }\end{array}$ & Newly constructed \\
\hline
\end{tabular}

Source: Compiled by the author from earlier studies

\section{Results and Discussion}

\subsection{Result}

In order to identify necessary variable combination of the research, the exploratory factor analysis (EFA) is employed to assess the level of observed variables which can be justified by the components and the distinctive characteristics of the factors. Then, only valid factors can be included for the next analysis. The EFA results of independent variables reveal that the four extracted factors (performance expectancy (PE), effort expectancy (EE), facilitating conditions (FC), social influence (SI)) have KMO of 0.747 (greater than 0.5), an eigenvalue of 1.694 (greater than 1), average variance extracted of $72.021 \%$ (greater than 50\%); the Bartlett test's significance level of 0.000 (lower than 5\%). It can be deduced that these factors are independent variables which are valid for the analyses. 
Table 2

Results of the EFA

\begin{tabular}{|c|c|c|c|c|c|}
\hline \multirow{2}{*}{ Observed variable } & \multicolumn{5}{|c|}{ Factor } \\
\hline & Performance expectancy (PE) & Effort & expectancy (EE) & Facilitating conditions (FC) & Social influence (SI) \\
\hline PE2 & 0.874 & & & & \\
\hline PE1 & 0.863 & & & & \\
\hline PE3 & 0.772 & & & & \\
\hline PE4 & 0.748 & & & & \\
\hline PE5 & 0.721 & & & & \\
\hline FC1 & & & 0.874 & & \\
\hline $\mathrm{FC} 2$ & & & 0.853 & & \\
\hline FC3 & & & 0.842 & & \\
\hline FC4 & & & 0.803 & & \\
\hline EE1 & & & & 0.873 & \\
\hline EE4 & & & & 0.859 & \\
\hline EE3 & & & & 0.762 & \\
\hline EE2 & & & & 0.755 & \\
\hline SI3 & & & & & 0.890 \\
\hline SI2 & & & & & 0.889 \\
\hline SI1 & & & & & 0.874 \\
\hline
\end{tabular}

Source: Computed by the Author.

Table 3

Results of EFA of dependent variable

\begin{tabular}{cc}
\hline Observed variable & Online purchase intention (PI) \\
\hline PI1 & 0.872 \\
PI3 & 0.868 \\
PI2 & 0.577 \\
\hline
\end{tabular}

Source: computed by the Author.

Table 4

Item - Total statistics

\begin{tabular}{|c|c|c|c|c|}
\hline Observed variable & Scale mean if item deleted & Scale variance if item deleted & $\begin{array}{c}\text { Corrected item - Total } \\
\text { correlation }\end{array}$ & $\begin{array}{c}\text { Cronbach's Alpha if item } \\
\text { deleted }\end{array}$ \\
\hline \multicolumn{5}{|c|}{ Performance expectancy (PE): Cronbach's Alpha $=0.868$} \\
\hline PE1 & 16.35 & 5.085 & 0.780 & 0.818 \\
\hline PE2 & 16.52 & 4.635 & 0.770 & 0.822 \\
\hline PE3 & 16.75 & 5.893 & 0.660 & 0.851 \\
\hline PE4 & 16.70 & 5.452 & 0.634 & 0.855 \\
\hline PE5 & 16.66 & 5.586 & 0.644 & 0.852 \\
\hline \multicolumn{5}{|c|}{ Effort expectancy (EE): Cronbach's Alpha $=0.843$} \\
\hline EE1 & 12.32 & 3.629 & 0.725 & 0.781 \\
\hline EE2 & 12.02 & 3.916 & 0.623 & 0.823 \\
\hline EE3 & 12.00 & 3.419 & 0.651 & 0.818 \\
\hline EE4 & 12.33 & 3.660 & 0.727 & 0.780 \\
\hline \multicolumn{5}{|c|}{ Facilitating conditions $(F C):$ Cronbach's Alpha $=0.875$} \\
\hline FC1 & 11.08 & 6.362 & 0.768 & 0.826 \\
\hline $\mathrm{FC} 2$ & 11.02 & 6.197 & 0.717 & 0.847 \\
\hline FC3 & 10.93 & 6.334 & 0.744 & 0.835 \\
\hline $\mathrm{FC} 4$ & 10.47 & 6.841 & 0.703 & 0.852 \\
\hline \multicolumn{5}{|c|}{ Social influence (SI): Cronbach's Alpha $=0.881$} \\
\hline SI1 & 8.70 & 1.897 & 0.750 & 0.852 \\
\hline SI2 & 8.57 & 1.842 & 0.770 & 0.835 \\
\hline SI3 & 8.39 & 2.140 & 0.809 & 0.811 \\
\hline \multicolumn{5}{|c|}{ Online purchase intention (PI): Cronbach's Alpha $=0.673$} \\
\hline PI1 & 8.27 & 1.491 & 0.601 & 0.430 \\
\hline PI2 & 8.08 & 1.870 & 0.308 & 0.792 \\
\hline PI3 & 8.17 & 1.345 & 0.578 & 0.445 \\
\hline
\end{tabular}

Source: computed by the Author.

The result of EFA of dependent variable reports that the extracted factor (online purchase intention (PI) has KMO of 0.578 (greater than 0.5), an eigenvalue of 1.846 (greater than 1), average variance extracted of $61.537 \%$ (greater than 50\%); the Bartlett test's significance level of 0.000 (lower than 5\%). Therefore, this factor is a dependent variable which has validity for next analyses. Subsequently, Cronbach's alpha is adopted to measure reliability and correlation among observed variables. This is associated with two aspects: internal item correlation and the inter correlation with total correlation. This test allows analysers to delete inappropriate variables and constrain garbage value in the model. Accordingly, only variable with the corrected item - total correlation being greater than 0.3 and alpha being greater than 0.6 is considered to be acceptable and fit for the analyses (Gliem \& Gliem, 2003). The results reveal that all variables with the corrected item - total correlation of greater than 0.3 and alpha of higher than 0.6, so all items are accepted and appropriate for the analyses. Eventually, the author performs the regression analysis to determine the correlation between dependent and independent variables. The regression model will describe the nexus and suggest the prediction of level of dependent variables based on the value of independent variables. Its results are presented in Table 5. Results of ANOVA test at the significance level of 0.000 indicates that the suggested linear regression model is appropriate with the dataset. Further, $\mathrm{R}^{2}$ which reflects explanatory level of the suggested 
regression model is used to evaluate the appropriateness of the model. It can be observed that $\mathrm{R}^{2}=50.7 \%$ which means that selected independent variables of the model can explain for $50.7 \%$ of fluctuation level of the online purchase intention. Eventually, it can be deduced that the online purchase intention is concurrently correlated to independent variables.

Table 5

Statistical parameters of variables

\begin{tabular}{lcc}
\hline & Standardized coefficients & Sig. \\
\hline Constant & & 0.649 \\
Performance expectancy (PE) & 0.364 & $0.000^{* * *}$ \\
Effort expectancy (EE) & 0.266 & $0.000^{* * *}$ \\
Facilitating conditions (FC) & 0.213 & $0.000^{* * *}$ \\
Social influence (SI) & 0.310 & $0.000^{* * *}$ \\
Observations & & 204 \\
ANOVA test (sig.) & 0.000 \\
R-squared & & $50.7 \%$ \\
\hline Note: ${ }^{* * *}$ indicates significance at the $1 \%$ level. & Source: computed by the Author.
\end{tabular}

\subsection{Discussion}

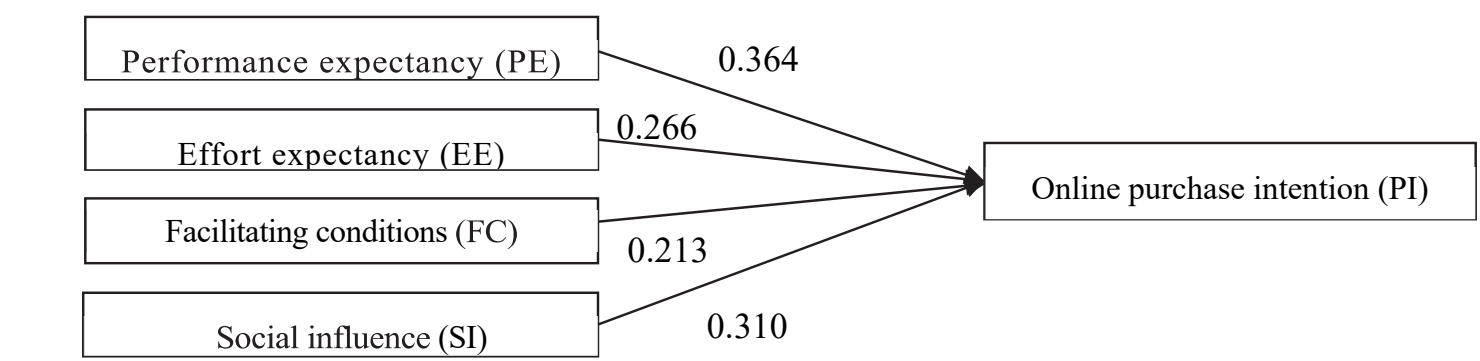

Source: computed by the Author.

Fig. 2. Results of testing the model

The findings interestingly reveal that the online purchase intention of Vietnamese users is significantly influenced by four factors: performance expectancy (PE), effort expectancy (EE), facilitating conditions (FC) and social influence (SI). These determinants are all positively correlated to the online purchase intention. Further, the results also report that:

- Performance expectancy (PE) which indicates the degree to which an individual believes that the online purchase intention will help him or her improve the work performance is the most significant influential factor of the user's online purchase intention with beta of 0.364 . This performance is shown by the simplicity and fastness the online transaction which are believed to be more efficient and time-saving. Consequently, it is supposed that the more the performance of the online purchase intention is, the more significant the impact is.

- Social influence (SI) is another determinant which exerts the second significant impact on the online purchase intention. This shows that each individual is usually affected by the important people like their friends, colleagues, family. These recommendations are effective communication channels which help increase the number of customers of purchase websites by enhancing the intention.

- The online purchase intention is also influenced by effort expectancy (EE) defined as the ease of use of the system. Obviously, a complicate website cannot attract many visits from users. This may lead to many mistakes in using. Therefore, the belief that a user does not need to make lots of effort using the system can positively affect his/her online purchase intention.

- The last influential factor in the online purchase intention of users is facilitating conditions (FC) defined as the degree to which a consumer believes that technical infrastructure develops to support in forming the online purchase intention. A widened technical infrastructure with high speed and a nationwide system of $3 \mathrm{G} \& 4 \mathrm{G}$ base transceiver stations obviously exert significant impact on the online purchase intention. In addition, users feel more comfortable if these websites are compatible with their equipment. A variety of integrated payment gateway can facilitate the purchase and enhance user's intention.

\section{Conclusions}

To explore the factors which influence the online purchase intention of Vietnamese users is vital for providing online businesses in Vietnam necessary information. With different influential factors in the user's intention, the firms are able to pay attention on each determinant to encourage consumers to purchase online as well as expand their businesses. Based on the empirical findings, some implications are suggested as follows:

- Improve performance expectancy: The results show that performance expectancy is the most influential factor in the user's online purchase intention. Therefore, online firms should make an effort to improve the performance expectancy of consumers. It is important to persuade users of the superiority of online purchase. Their management as integrated with marketing teams should make an effort to communicate this value to their potential consumers. More users should be attracted to give the online system a try so as to experience this superiority as compared to traditional shopping channels.

- Value social influence: Consumers tend to have a belief in their acquaintances such as family, friends, colleagues who have 
experienced and evaluated the online purchase. Despite their subjectivity, these opinions significantly affect those who have hesitation in online shopping. Thus, it is necessary for online firms to enhance their belief through positive recommendations from their acquaintances who have experienced the convenience, safety in payment and after-sales services of online purchase. In addition, they can run big promotions for group or family buying. This contributes in enhancing the social influence on user's online purchase intention.

- Enhance effort expectancy: Online firms should take account of designing user-friendly websites with appropriate language as well as fast and precise processing speed. This will catch user's first impression on these websites during their online purchase. Moreover, the firms need to update as well as popularize the detailed instruction in order to facilitate the shopping.

- Improve facilitating conditions: Online firms need to facilitate the online purchase with user-friendly websites which are compatible with user's equipment such as computers, cell phones, tablets... besides, various and convenient methods of payment play a vital role to bring users good conditions. In fact, there are a big number of Vietnamese users trusting the quality as well as information which are supplied by popular international websites like Ebay, Amazon but cannot do shopping due to lack of required payment methods. Consequently, a variety of integrated payment gateway can facilitate the purchase and enhance user's intention. Also, the development of wide technical infrastructure with high speed and a nationwide system of $3 \mathrm{G} \& 4 \mathrm{G}$ base transceiver stations contributes to this purpose. It is essential for consideration by the authorities.

By adopting the Unified Theory of Acceptance and Use of Technology (UTAUT), the paper achieved its objectives of identifying the influential factors in Vietnamese user's intention to purchase online. Hopefully, these implications will contribute to encourage consumers to do more online purchase and improve firm performance. Nevertheless, the paper has its limitations when only examining the online purchase intention, but not the behaviour. Although the intention is obviously associated with the behaviour, this correlation is influenced by many factors. Therefore, future studies on factors affecting the online purchase behaviour or the nexus between the online purchase intention and behaviour are proposed.

\section{References}

Abrahão, R. D. S., Moriguchi, S. N., \& Andrade, D. F. (2016). Intention of adoption of mobile payment: An analysis in the light of the Unifified Theory of Acceptance and Use of Technology (UTAUT). RAI Revista de Administração e Inovação, 13, 221 -230.

Ajzen, I. (1991). The Theory of Planned Behavior. Organizational Behavior and Human Decision Processes, 50(2), $179-211$.

eMarketer. (2018). Worldwide Retail and Ecommerce Sales: eMarketer's Updated Forecast and New Mcommerce Estimates for 20162021.

Escobar-Rodríguez, T., \& Carvajal-Trujillo, E. (2014). Online purchasing tickets for low cost carriers: An application of the unifified theory of acceptance and use of technology (UTAUT) model. Tourism Management, 43, 70-88.

Gliem, J. A., \& Gliem, R. R. (2003). Calculating, interpreting, and reporting Cronbach's alpha reliability coefficient for Likert-type scales. Midwest Research-to-Practice Conference in Adult, Continuing, and Community Education.

He, D., Lu, Y., \& Zhou, D. (2008). Empirical Study of Consumers' Purchase Intentions in C2C Electronic Commerce. Tsinghua Science \& Technology, 13(3), 287-292.

Howard, J. A., \& Sheth, J. N. (1967). A Theory of Buyer behavior in Moyer, R. (ed) Changing Marketing System. Proceedings of the 1967 Winter Conference of the American Marketing Association Â, 253-262.

Internet World Stats. (2018). Internet usage statistics and Internet users in the world distribution by world region.

Isaac, O., Abdullah, Z., Aldholay, A. H., \& Ameen, A. A. (2019). Antecedents and outcomes of internet usage within organisations in Yemen: An extension of the Unified Theory of Acceptance and Use of Technology (UTAUT) model. Asia Pacific Management Review, 24(4), 335-354.

Martín, H. S., \& Herrero, A. (2012). Inflfluence of the user's psychological factors on the online purchase intention in rural tourism: Integrating innovativeness to the UTAUT framework. Tourism Management, 33, 341-350.

Raza, M. A., Ahad, M. A., Shafqat, M. A., Aurangzaib, M., \& Rizwan, M. (2014). The Determinants of Purchase Intention towards Counterfeit Mobile Phones in Pakistan. Journal of Public Administration and Governance, 4(3), 1-19.

Roy, S., \& Ghose, S. (2006). Internet adoption as a two-stage transitio: Converting Internet Non-Users to Internet Users and to Online Buyers. International Journal of Market Research, 48(3),321-349.

Sarfaraz, J. (2017). Unified Theory Of Acceptance And Use Of Technology (UTAUT) Model-Mobile Banking. Journal of Internet Banking and Commerce, 22(3), 1-20.

Singh, A., Alryalat, M. A. A., Alzubi, J. A., \& Sarma, H. K. D. (2017). Understanding Jordanian Consumers' Online Purchase Intentions: Integrating Trust to the UTAUT2 Framework. International Journal of Applied Engineering Research, 12(20), 10258-10268.

Tirtiroglu, E., \& Elbeck, M. (2008). Qualifying Purchase Intentions Using Queuing Theory. Journal of Applied Quantitative Method, 3(2), $167-178$.

Venkatesh, V., Morris, M. G., Davis, G. B., \& Davis, F. D. (2003). User acceptance of information technology: toward a unified view. MIS Quarterly: Management Information Systems 27(3), 425-478.

Vietnam E-commerce Association. (2018). The 2018 Vietnam E-Business Index (EBI). http://www.vaip.org.vn/download/2019/B\%C3\%A10\%20c\%C3\%A10\%20EBI\%202018\%20290118\%20Final\%20En.pdf

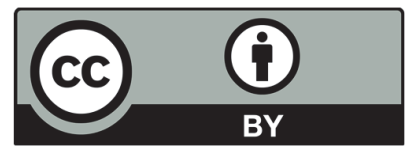

(C) 2020 by the authors; licensee Growing Science, Canada. This is an open access article distributed under the terms and conditions of the Creative Commons Attribution (CC-BY) license (http://creativecommons.org/licenses/by/4.0/). 